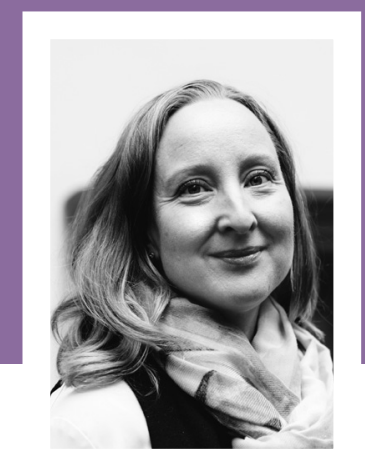

\title{
P̈̈̈KKIRJOITUS
}

\section{AIKUISKASVATUKSELLA RAKENNETAAN TULEVAISUUTTA KORONAKRIISIN JÄLKEEN}

$\mathrm{T}$ IEDEYHTEISÖ ON TOISTAISEKSI VARSIN pienimuotoisesti tutkinut koronakriisin vaikutuksia aikuiskoulutukseen ja oppimiseen. Monen aikuisopiskelijan opinnot ovat olleet katkolla poikkeusjärjestelyiden, poissaolojen ja keskeyttämisten takia. Poikkeusolojen vaikutukset epäviralliseen ja epämuodolliseen oppimiseen ovat myös olleet merkittäviä. Etätyöhön siirtyminen, lomautukset ja pahimmassa tapauksessa irtisanomiset ovat vaikeuttaneet uusien tietojen ja taitojen kartuttamista. Talousjärjestö OECD arvioi (2021), että oppimismahdollisuuksia on koronakriisin aikana ollut tarjolla vain noin neljännes verrattuna siihen, kuinka paljon työntekijät normaalioloissa työnsä ohessa oppivat.

KORONAKRIISI TEKI NÄKYVÄKSI monenlaisia SOsiaalisen eriarvoisuuden muotoja, eikä se kohdellut aikuisväestöä oppimishaasteiden ja -mahdollisuuksien suhteenkaan tasaveroisesti. Työssä oppimisen puutteet kohdistuivat monikertaisesti ammatteihin, joissa opitaan asioita itse tekemällä sekä työkavereiden kanssa käydyn vuorovaikutuksen ja esimerkkien avulla (OECD 2021). Erityisesti matkailu- ja kulttuurialoilla monelta loppuivat työt kokonaan, ja työttömyyden vaihtoehtona osa päätti vaihtaa alaa ja lähti opiskelemaan uuteen ammattiin.
Tietotyötä tekevien kehittymismahdollisuudet heikkenivät suhteessa vähiten, sillä etätyö ja virtuaaliset oppimisympäristöt mahdollistivat työssäoppimisen ja aikuisopintojen jatkumon. Etätyöhön siirtyminen oli tosin itsessään valtava oppimishaaste. Verkkovälitteinen oppiminen ja työ ovat muuttaneet suhdettamme sekä toisiimme että itseemme. Vaikka etätyö voi olla tehokasta ja säästää paikasta toiseen siirtymisen vaivan, se synnyttää irrallisuuden, pinnallisuuden ja "eimissään" olemisen kokemuksia, kuten Tuula Kiander ja Jussi Onnismaa oivaltavasti kirjoittavat (s. 263).

Yksi tärkeimpiä syitä osallistua aikuiskoulutukseen on juuri muiden ihmisten tapaaminen ja verkostoituminen. Tapamme oppia yhdessä rapistuvat, jos sosiaalista kanssakäymistä rajoitetaan liian pitkään ja liian kokonaisvaltaisesti.

MINKÄLAISEEN OPPIMISEN maailmaan palaudumme poikkeusolojen jälkeen? Tutkittua tietoa tarvitaan lisää muun muassa siitä, kuinka osallistuminen aikuiskoulutukseen ja -oppimiseen on muuttunut. Millaisia uusia mahdollisuuksia tai osallistumisen esteitä uudet virtuaaliset oppimisympäristöt ovat synnyttäneet? Mitkä aikuisryhmät tarvitsevat erityistä tukea kuroakseen kiinni koronakriisin synnyttämää 


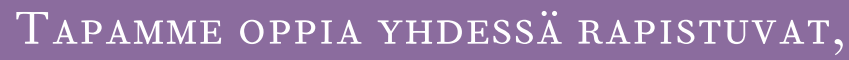

JOS SOSIAALISTA KANSSAKÄYMISTÄ RAJOITETAAN

LIIAN PITKÄ̈̈N JA LIIAN KOKONAISVALTAISESTI.

oppimisvajetta? Entä millaisia uusia etäyhteisöllisyyden, keskinäisen avunannon ja oppimisen tiloja kriisistä selviytyminen on luonut? Esimerkiksi Heidi Lehtovaara ja Tanja Namrood tuovat esiin (s. 258), kuinka älypuhelinten hyödyntäminen maahan muuttaneiden naisten ohjauksessa korona-aikana lisäsi varsinkin pienten lasten äitien osallistumismahdollisuuksia.

Aikuiskasvatuksella on koronan jälkeisessä ajassa kauaskantoisia yhteiskunnallisia tehtäviä. Sosiaalisen elämän rajoittaminen, yksinäisyys ja ulkopuolisuus ovat käristäneet sosiaalisia ongelmia. Euroopan aikuiskasvatusjärjestö EAEA (European Association for the Education of Adults) nostaa kannanotossaan (EAEA 2020) esiin aikuiskasvatuksen tehtävän eurooppalaisen yhtenäisyyden ja solidaarisuuden vahvistamisessa. Unesco (2020) puolestaan korostaa globaalia kansalaiskasvatusta ja kriittistä medialukutaitoa vastavoimana konfliktien ja ääriliikkeiden voimistumiselle poikkeusoloissa. Kvs-säätiö (Kansanvalistusseura sr.) julkaisi koronavuonna aikuisten mediakasvatusoppaan englannin ja arabian kielillä vahvistaakseen kansalaisyhteiskuntaa, demokratiaa ja tutkittuun tietoon pohjautuvaa viestintää (Knuuti 2020).

Aikuiskasvatuksen tehtävä poikkeusoloista palautuessa on löytää keinoja siihen, että arkisivistymisen, oppimisen ja kouluttautumisen mahdollisuudet säilyvät kaikille avoimina. Joustavuutta tarvitaan jatkossa lähiopetuksen ja etäopetuksen yhdistämiseen. On tärkeää kaventaa eri aikuisryhmien välistä, osallistumista eriarvoistavaa digitaalista kuilua. Samalla on syytä muistaa terveen kriittinen suhde verkkovälitteiseen työhön ja opiskeluun.

Aikuisten osallistumista ja oppimisen mielekkyyttä kannattelevat toiset ihmiset, niin opiskelu- ja työtoverit kuin opettajat ja ohjaajatkin. Aikuiskasvatuksen tulevaisuus rakentuu poikkeusolojen jälkeen onnistuneiden kohtaamisten varaan sekä lähellä, että ajasta ja paikasta riippumatta.

Ulpukka Isopahkala-Bouret

\section{Lisää aiheesta:}

EAEA (2020). Resilience of Individuals, Communities and Economies: We need more Adult Learning and Education in and after the Coronavirus Pandemic. EAEA Statement. https://eaea.org/wp-content/ uploads/2020/04/EAEA-statement-on-COVID-19-andALE.pdf

Knuuti, K. (toim.) (2020). Media Guide - Media Literacy for Adults. Kvs-säätiö. www.mediaguide.fi

OECD (2021). Adult Learning and COVID-19: How much informal and non-formal learning are workers missing? https://www.oecd.org/coronavirus/policyresponses/adult-learning-and-covid-19-how-muchinformal-and-non-formal-learning-are-workers-missing56a96569/\#section-d1e234

Unesco (2020). Adult Learning and Education and COVID-19. UNESCO Institute for Lifelong Learning. https://unesdoc.unesco.org/ark:/48223/pf0000374636 